\title{
ANALISIS PREDIKSI DEBIT SUNGAI AMPRONG DENGAN MODEL ARIMA (AUTOREGRESSIVE INTEGRATED MOVING AVERAGE) SEBAGAI DASAR PENYUSUNAN POLA TATA TANAM
}

\author{
Wiwin Sri Rahayu ${ }^{1}$, Pitojo Tri Juwono ${ }^{2}$, Widandi Soetopo \\ ${ }^{1}$ Mahasiswa Magister Teknik Pengairan, Fakultas Teknik, Universitas Brawijaya, Malang, Jawa Timur \\ ${ }^{2}$ Dosen Jurusan Pengairan, Fakultas Teknik, Universitas Brawijaya, Malang, Jawa Timur, Indonesia \\ email: wiwinsrirahayu13@gmail.com
}

\begin{abstract}
ABSTRAK: Penentuan ketersediaan air yang akurat dalam periode 10 harian dari Sungai Amprong memegang peranan penting dalam tata tanam untuk menunjang proses produksi pertanian pada DI. Kedungkandang, karena apabila ketersediaan air tidak ditentukan dengan tepat maka akan terjadi kesalahan dalam pengaturan air irigasi dan penggunaannya tidak sesuai dengan yang diharapkan. Untuk mengatasi permasalahan tersebut diperlukan sebuah sistem analisis yang mampu melakukan prediksi dengan baik. Salah satu model runtun waktu tersebut adalah model ARIMA (Autoregressive Intregated Moving Average). Model dibangun dengan data debit sepanjang 9 periode yaitu 2008/2009 s/d 2016/2017, untuk memprediksi debit periode 2017/2018. Dari sepuluh model tentatif yang diperoleh, hanya terdapat lima model yang layak digunakan. Model terbaik yaitu model ARIMA $(2,0,1)(1,2,1)^{36}$ dengan nilai MSE $=22,90 ; \mathrm{KR}=$ 6,$00 ;$ MSD $=8,05 ;$ MAD = 2,04; MAPE $=18,53$ dan MPE $=-8,98$. Pada MT II intensitas tanam padi meningkat dari $55,79 \%$ menjadi $64,50 \%$, dan produksi GBK meningkat sebesar $13,50 \%$. Sedangkan pada MT III intensitas tanam padi meningkat dari 37,22\% menjadi 49,99\%, dan produksi GBK meningkat sebesar 25,54\%.
\end{abstract}

Kata kunci: ARIMA, Intensitas tanam, Prediksi debit, Pola tata tanam.

ABSTRACT: An accurate determination of water availability in the 10-day period of the Amprong River has an important role in the planting system to support the agricultural production process in DI. Kedungkandang, because if the availability of water is not precisely determined, there will be an error in regulating irrigation water and its use is not as expected. To overcome these problems, an analysis system is needed that is able to make predictions well. One of the time series models is the ARIMA (Autoregressive Intregated Moving Average) model. The model was built by 9 period discharge data, namely 2008/2009 until 2016/2017, to predict the discharge of period 2017/2018. Of the ten tentative models obtained, there are only five models that are worth using. The best model is the ARIMA model $(2,0,1)(1,2,1)^{36}$ with the value of MSE $=22,90 ; K R=6.00 ; M S D=8.05 ; M A D=2.04 ; M A P E=18.53$ and $M P E=-8.98$. In second crop season the crop intensity of paddy increased from $55.79 \%$ to $64.50 \%$, and the production of GBK increased by $13.50 \%$. While the third crop season paddy crop intensity increased from $37.22 \%$ to $49.99 \%$, and GBK production increased by $25.54 \%$.

Key words: ARIMA, Crop intensity, Discharge Prediction, Planting pattern.

Prediksi debit aliran sungai sangat dibutuhkan dalam penerapan hidrologi di antaranya manajemen dan perencanaan sumber daya air, baik dalam jangka menengah maupun jangka panjang. Informasi debit rata-rata dalam suatu periode dapat memberikan gambaran potensi sumberdaya air yang dapat dimanfaatkan dari suatu daerah aliran sungai, sehingga perencanaan pemanfaatannya dapat dilakukan dengan tepat.

Penentuan ketersediaan air yang akurat dalam periode 10 harian dari Sungai Amprong 
memegang peranan yang sangat penting dalam perencanaan pola tata tanam untuk menunjang proses produksi pertanian pada DI. Kedungkandang, karena apabila ketersediaan air tidak ditentukan dengan tepat, maka akan terjadi kesalahan dalam pengaturan air irigasi dan penggunaannya tidak sesuai dengan yang diharapkan.

Untuk mengatasi permasalahan tersebut diperlukan sebuah sistem analisis yang mampu melakukan prediksi dengan baik. Debit sungai mempunyai perilaku berulang-ulang dalam periode yang sama, sehingga dapat dibuat suatu model runtun waktu dan akhirnya dapat diperoleh pola debit sungai tersebut dalam suatu rumus matematika. Salah satu model runtun waktu tersebut adalah model ARIMA (Autoregressive Intregated Moving Average) yang dikembangkan oleh Box dan Jenkins (1976).

Pola data debit sungai seringkali tidak jelas, namun dengan model ARIMA identifikasi pola dapat dilakukan sehingga dapat digunakan untuk meramalkan pola yang akan datang. Model ARIMA sangat baik ketepatannya untuk peramalan jangka pendek, sedangkan untuk peramalan jangka panjang ketepatan peramalannya kurang baik. Untuk keperluan prediksi ketersediaan air satu tahun yang akan datang dalam perencanaan pola tata tanam, model ARIMA ini tepat untuk digunakan karena peramalan yang dilakukan adalah peramalan jangka pendek.

ARIMA merupakan model yang bersifat black box. Model ini tidak berusaha mengetahui faktor-faktor yang mempengaruhi sistem tersebut. Sistem semata-mata dianggap sebagai suatu pembangkit proses, karena tujuan utama dari metode ini adalah menduga "apa" yang akan datang, bukan mengetahui "mengapa" hal itu terjadi.

Model ARIMA adalah model yang secara penuh mengabaikan independen variabel dalam membuat peramalan. ARIMA menggunakan nilai masa lalu dan sekarang dari variabel dependen untuk menghasilkan peramalan jangka pendek yang akurat. ARIMA cocok jika observasi dari deret waktu (time series) secara statistik berhubungan satu sama lain (dependent). Peramalan dengan metode ARIMA Box-Jenkins pada umumnya akan memberikan hasil yang lebih baik dari metodemetode peramalan yang lain, sebab metode ini tidak mengabaikan kaidah-kaidah pada data deret waktu (Mulyana, 2004).
Nigam dkk. (2009) menyatakan bahwa model ARIMA adalah pendekatan yang tepat untuk model data hidrologi yang sering menunjukkan auto-korelasi dengan waktu dan perlu penjelasan yang tepat dari dinamika mendasar yang tidak dapat dilakukan dengan metode peramalan statistik sederhana seperti analisis regresi. Data curah hujan yang diramalkan menunjukkan korelasi yang sangat baik dengan data eksisting. Hal ini menunjukkan model ARIMA yang dipilih mempunyai tingkat kepercayaan yang baik (Zakaria dkk., 2012). Valipour, dkk. (2012) menyatakan bahwa model ARIMA memiliki kinerja yang lebih baik daripada model ARMA karena membuat time series stasioner, di kedua fase kalibrasi dan peramalan, model ARIMA dapat digunakan untuk peramalan debit inflow bulanan yang sesuai untuk 12 bulan ke depan. Keakuratan kedua model ARMA dan ARIMA meningkat dibandingkan dengan studi sebelumnya, karena kenaikan jumlah parameter autoregressive dan moving average dalam model ini. Metode ARIMA menghasilkan model yang lebih baik daripada ARMA (Valipour dkk., 2013). Pemodelan debit Sungai Konto di Jawa Timur dengan Model ARIMA(1,1,1) dan ARIMA $(2,1,1)$ terbukti lebih tepat dibandingkan metode debit andalan untuk memperkirakan debit inflow Waduk Selorejo di Malang (Pramujo dkk., 2014). Hasil analisa pola operasi Waduk Sengguruh diketahui bahwa debit aktual maupun ramalan tidak memiliki selisih yang signifikan, hal ini menunjukkan bahwa metode peramalan dengan model ARIMA baik untuk digunakan (Hanggara dkk., 2015).

Tujuan dari kajian ini adalah untuk mengetahui prediksi debit Sungai Amprong periode satu tahun berikutnya dengan menggunakan model ARIMA kemudian dibandingkan dengan debit observasi. Kemudian dari debit tersedia dari model ARIMA tersebut dapat disusun pola tata tanam DI Kedungkandang untuk selanjutnya dibandingkan dengan pola tata tanam eksisting.

\section{BAHAN DAN METODE}

Studi ini berlokasi di Bendung Kedungkandang pada Sungai Amprong, Kecamatan Kedungkandang Kota Malang. DAS Amprong merupakan daerah aliran sungai yang terletak di Kota Malang dan Kabupaten Malang dengan luas sekitar 24.984 ha. Air dari Sungai Amprong ini dimanfaatkan 
oleh Daerah Irigasi Kedungkandang dengan baku sawah seluas 5.169 Ha melalui Bendung Kedungkandang. Lokasi studi digambarkan pada Gambar 1.

\section{Data}

Data yang dibutuhkan adalah data debit Sungai Amprong yang terukur di Bendung Kedungkandang sepanjang 10 periode (periode tahun 2008/2009 s/d 2017/2018) yang diperoleh dari UPT PSDA di Malang, Dinas PU SDA Provinsi Jawa Timur. Selain itu juga diperlukan data kondisi irigasi berupa data pola tanam dan luas lahan.

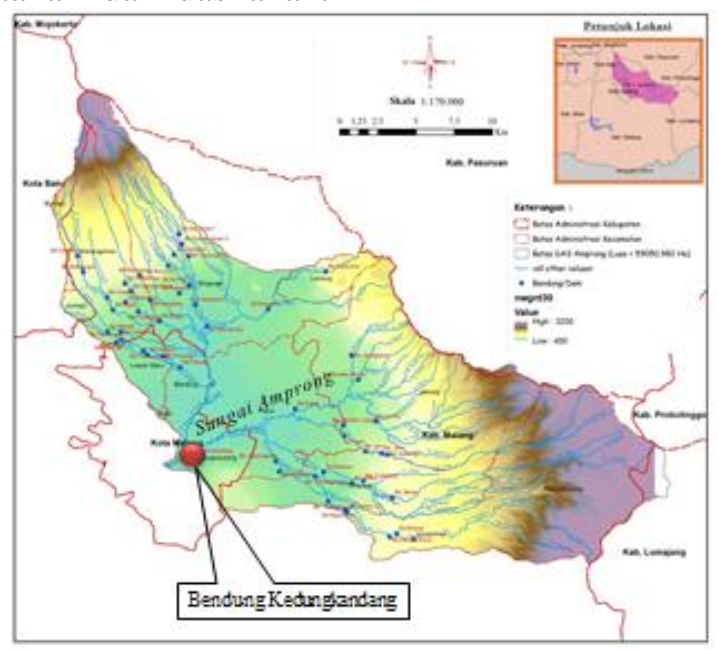

Gambar 1. Lokasi Studi

\section{Model ARIMA}

Model ARIMA dibagi dalam 3 unsur yaitu: model autoregressive (AR), moving average (MA), dan integrated (I). Ketiga unsur ini dimodifikasi sehingga membentuk model baru, misalnya model autoregressive dan moving average (ARMA). Bentuk umumnya adalah ARIMA $(p, d, q)$ di mana $p$ menyatakan ordo autoregressive, $d$ menyatakan ordo Integrated dan $q$ menyatakan ordo moving average.

Maksud dari autoregressive yaitu nilai $x$ dipengaruhi oleh nilai $x$ periode sebelumnya hingga periode ke- $p$. Jadi yang berpengaruh di sini adalah variabel itu sendiri. Maksud dari moving average yaitu nilai variabel $x$ dipengaruhi oleh error dari variable $x$ tersebut. Sedangkan integrated menyatakan difference dari data. Maksudnya bahwa dalam membuat model ARIMA syarat yang harus dipenuhi adalah stasioneritas data. Apabila data stasioner pada level maka ordonya adalah 0 , namun apabila stasioner pada difference pertama maka ordonya 1 , dan seterusnya.

\section{Pola Tata Tanam}

Pola tata tanam adalah pola mengenai rencana tata tanam yang terdiri dari pengaturan waktu tanam, jenis tanaman, tempat atau lokasi tanaman dan luas areal yang memperoleh hak atas air. Tujuan pemakaian pola tata tanam adalah untuk menghemat persediaan air irigasi sehingga pemakaian bisa efisien dengan hasil produksi tetap tinggi.

Dua hal pokok yang mendasari diperlukannya tata tanam adalah:

a. Ketersediaan air irigasi (dari sungai) di musim kemarau yang terbatas.

b. Air yang terbatas harus dimanfaatkan sebaik-baiknya sehingga tiap petak mendapatkan air secukupnya sesuai jumlah yang dibutuhkan.

\section{Metode Analisa}

\section{a. Tahap persiapan data}

Data sepanjang 9 periode (periode tahun 2008/2009 s/d 2016/2017) akan digunakan dalam proses peramalan, sedangkan data untuk tahun 2017 digunakan untuk proses kalibrasi atau uji keandalan model. Menyesuaikan dengan pola tata tanam DI. Kedungkandang yang dilaksanakan dalam 10 harian, maka data debit rata-rata harian dikonversi menjadi data debit rata-rata 10 harian.

\section{b. Tahap identifikasi}

Pola data debit rata-rata 10 harian dapat diketahui dengan cara memplot grafik data yang sudah dimasukkan ke dalam worksheeet software Minitab 16.

Setelah diketahui pola data, selanjutnya diuji stasioneritas data, karena syarat yang harus dipenuhi pada model ARIMA ini salah satunya adalah data harus stasioner terhadap ragam dan rata-rata. Plot Box-Cox dilakukan untuk menguji kestasioneran data terhadap ragam dan nilai tengah. Data stasioner terhadap ragam jika nilai $\lambda=1$. Apabila data belum stasioner terhadap ragam, maka data perlu ditransformasikan untuk mencapai stasioneritas terhadap ragam.

Pengujian stasioneritas terhadap ratarata dilakukan jika data sudah stasioner terhadap ragam. Plot ACF (Auto Correlation Function) dilakukan untuk mengetahui stasioneritas data terhadap ratarata. Data yang stasioner terhadap rata-rata ditandai dengan lag yang tidak berpola 
(acak) dan tidak mengandung unsur musiman. Apabila data belum stasioner terhadap rata-rata, maka data perlu distasionerkan dengan differencing sampai diperoleh data yang stasioner terhadap ratarata.

c. Tahap menentukan model sementara (tentative)

Pada tahap ini akan ditentukan $p, d$ dan $q$. Penentuan $p$ dan $q$ dengan bantuan korelogram autokorelasi (ACF) dan korelogram autokorelasi parsial (PACF). Sedangkan $d$ ditentukan dari tingkat stasioneritasnya. ACF di sini mengukur korelasi antara pengamatan dengan lag ke- $k$ sedangkan PACF merupakan pengukuran korelasi antara pengamatan dengan lag ke- $k$ dan dengan mengontrol korelasi antara dua pengamatan dengan lag kurang dari $k$.

\section{d. Tahap menentukan model akhir}

Penentuan model akhir dengan mencocokkan pada kriteria evaluasi model:

- Residual peramalan bersifat acak. Untuk memastikan apakan model sudah memenuhi syarat ini, dapat digunakan indikator Box-Ljung Statistic. Dari indikator ini selanjutnya dapat diketahui bahwa nilai P-value untuk uji statistik ini lebih besar dari 0,05 yang menunjukkan bahwa residual sudah acak.

- Model parsimonious (model sudah dalam bentuk yang paling sederhana)

- Kondisi inverbilitas ataupun stasioneritas harus terpenuhi. Hal ini ditunjukkan oleh jumlah koefisien MA atau AR dimana masing-masing harus kurang dari satu.

- Model harus memiliki MS dan SS yang kecil.

- Grafik ACF dan PACF dari residual menunjukkan pola cut-off, yang berarti bahwa residual memang sudah acak.

\section{e. Tahap peramalan}

Pada tahap ini model terpilih dimasukkan dalam software Minitab 16 untuk kemudian proses peramalan dilakukan oleh software bantu tersebut.

\section{f. Tahap kalibrasi / uji keandalan model}

Hasil prediksi debit dibandingkan dengan data pembanding yang sudah dipersiapkan sebelumnya untuk mengetahui keandalan model dalam melakukan peramalan. Kalibrasi dilakukan dengan mencari nilai MSD (Mean Squared Deviation), MAD (Mean Absolute Deviation), MAPE (Mean Absolute Percentage Error), MPE (Mean Percentage Error) dan KR (Kesalahan Relatif).

\section{g. Tahap analisa pola tata tanam DI Kedungkandang}

Pada tahap ini data debit hasil prediksi digunakan sebagai data untuk merencanakan pola tata tanam DI. Kedungkandang. Kemudian pola tata tanam tersebut dibandingkan dengan pola tata tanam yang sudah ada.

\section{HASIL DAN PEMBAHASAN}

Debit Rata-rata 10 Harian

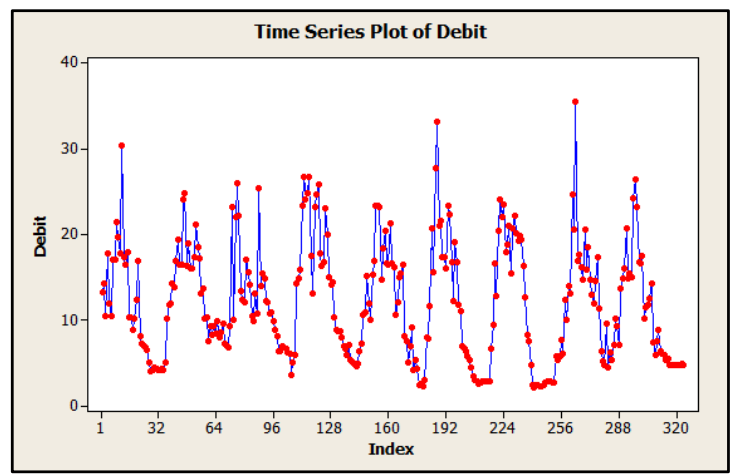

Gambar 2. Plot Data Debit Rata-rata 10 Harian Bendung Kedungkandang

Debit rata-rata 10 harian Bendung Kedungkandang yang dikonversi dari debit rata-rata harian diplot pada grafik sebagaimana disajikan pada Gambar 2, di mana grafik tersebut mengindikasikan pola musiman. Data belum stasioner pada rata-rata dan varian data terlalu besar. Data juga belum stasioner terhadap ragam. Kestasioneran terhadap ragam dapat dibuktikan dari plot Box-Cox, sedangkan kestasioneran terhadap nilai tengah dapat dibuktikan dengan plot ACF.

\section{Uji Stasioneritas terhadap Ragam}

Gambar 3 menunjukkan bahwa pada data debit rata-rata 10 harian Bendung Kedungkandang setelah diuji dengan plot Box-Cox, nilai $\lambda \neq 1$, yang berarti bahwa data tidak stasioner terhadap ragam. Selanjutnya dilakukan 
transformasi Box-Cox sampai diperoleh nilai $\lambda=1$. Dari transformasi pertama seperti yang ditunjukkan pada Gambar 4, diperoleh bahwa data hasil trasnformasi pertama sudah stasioner terhadap ragam, yang ditunjukkan oleh nilai $\lambda=1$.

\section{Uji Stasioneritas terhadap Rata-rata}

Pengujian stasioneritas terhadap rata-rata dilakukan jika data sudah stasioner terhadap ragam. Plot ACF yang ditunjukkan pada Gambar 5 menunjukkan bahwa data belum stasioner terhadap rata-rata, ditandai dengan lag yang masih berpola (tidak acak) dan mengandung musiman. Oleh karena itu data perlu distasionerkan melalui differencing satu kali. Setelah itu dilakukan plot ACF dari data yang sudah melalui differencing satu kali tersebut. Gambar 6 menunjukkan bahwa data masih belum stasioner terhadap rata-rata sehingga perlu dilakukan differencing yang kedua. Gambar 7 menunjukkan bahwa plot ACF data yang sudah melalui defferencing dua kali telah stasioner terhadap rata-rata, yang ditunjukkan oleh pola yang tidak teratur.

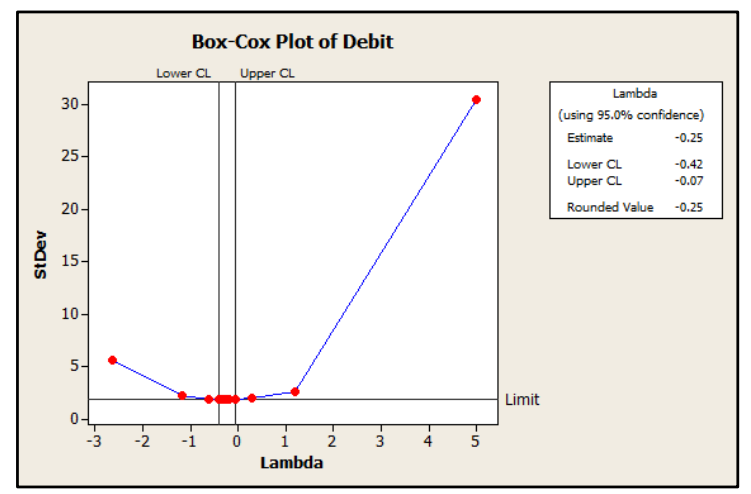

Gambar 3. Plot Box-Cox

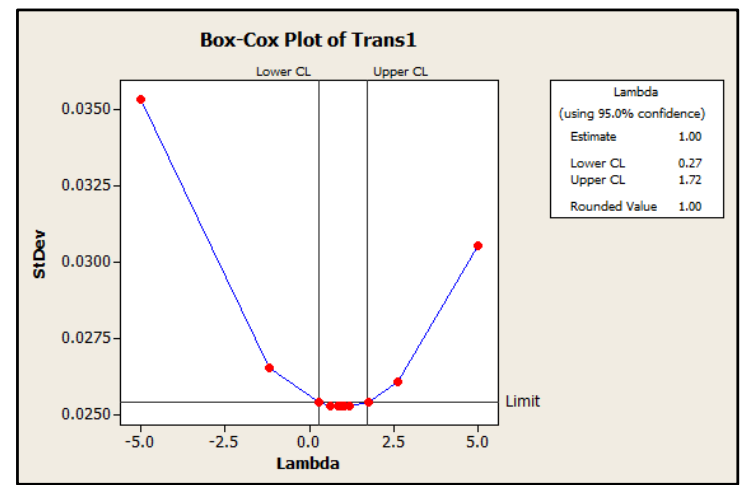

Gambar 4. Plot Box-Cox Transformasi Pertama
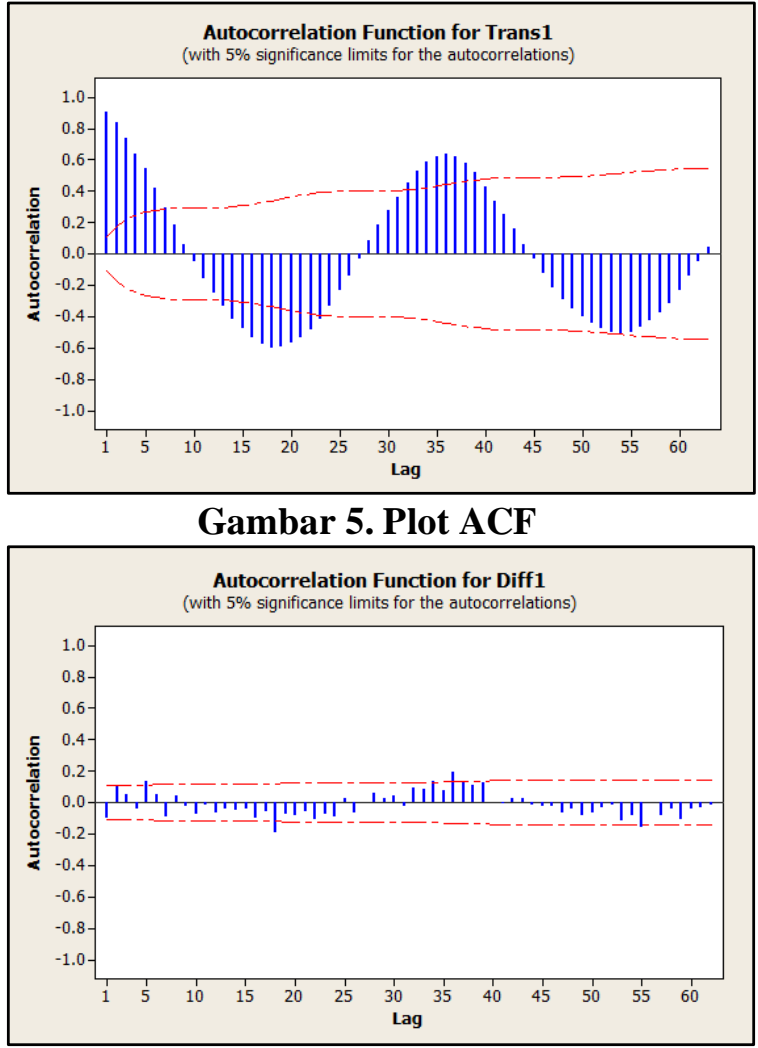

Gambar 6. Plot ACF Differencing Satu Kali

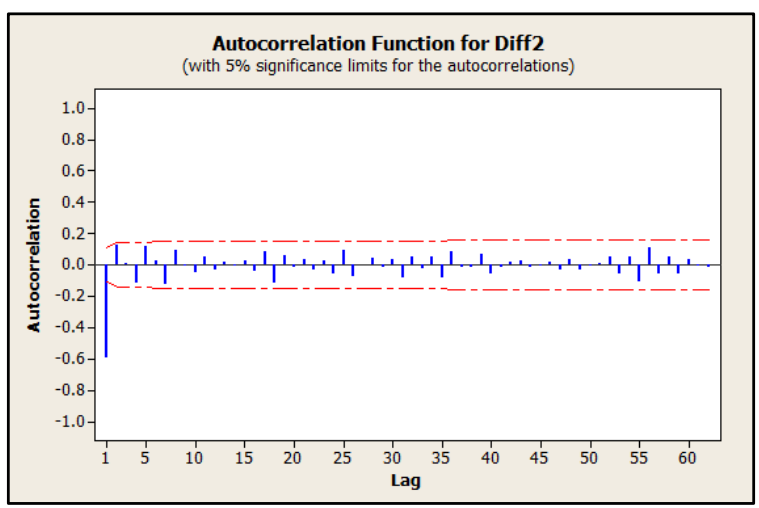

Gambar 7. Plot ACF Differencing Dua Kali

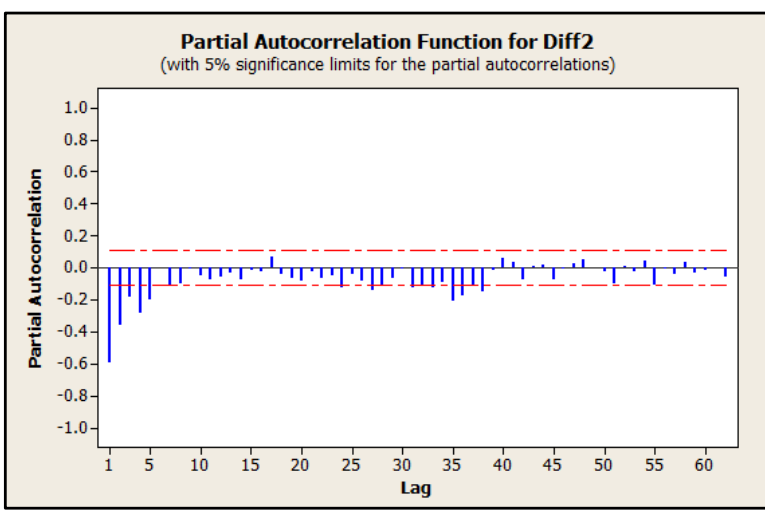

Gambar 8. Plot PACF Differencing Dua Kali 
Model ARIMA $(p, d, q)(P, D, Q)^{\mathrm{S}}$

Dari plot ACF setelah differencing dua kali pada Gambar 7 terdapat cut off setelah lag 1 sehingga diperoleh model tentatif untuk MA non musiman adalah $q=1$ dan model tentatif untuk MA musiman adalah $Q=1$. Karena adanya proses differencing dua kali, maka diperoleh ordo $D=2$. Cut off lag seasonal terjadi pada lag 36, sehingga nilai ordo $S=36$. Plot PACF digunakan untuk menentukan ordo $p$ dan $P$ dari model AR. Plot PACF pada Gambar 8 menjelaskan bahwa titik-titik observasi debit rata-rata 10 harian Bendung Kedungkandang bersifat dies down. Model tentatif untuk model AR non musiman adalah $p=1,2,3,4$ dan 5 sedangkan ordo AR musiman adalah $P=1$.

Dari tahapan-tahapan tersebut diperoleh nilai dari masing-masing parameter model ARIMA yang kemudian diperoleh beberapa model tentatif yang disajikan pada Tabel 1 .

Pengujian kelayakan model pada Tabel 1 dilakukan dengan menggunakan uji statistik Ljung-Box. Model tidak layak jika p-value kurang dari 0,05 pada salah satu atau semua lag. Hasil pengujian kelayakan model menunjukkan bahwa hanya terdapat 5 (lima) model tentatif yang layak digunakan.

Model terbaik akan dipilih pada tahapan kalibrasi model. Kalibrasi model dilakukan dengan membandingkan data debit hasil peramalan metode ARIMA terhadap data debit eksisting.

\section{Pemilihan Model Terbaik}

Kesalahan relatif dari model ARIMA yang layak dapat digunakan untuk memilih model yang terbaik. Model ARIMA yang terbaik dipilih dari model yang memiliki kesalahan relatif paling kecil. Kesalahan relatif dihitung dengan cara membandingkan antara debit data model dengan debit data historis.

Dari debit historis dan debit hasil peramalan model ARIMA, selanjutnya kita dapat menghitung Kesalahan Relatif (KR) masing-masing model, yaitu persentase perbandingan antara selisih volume model dengan volume historis, dibandingkan dengan volume historis. Kesalahan Relatif (KR) digunakan untuk memilih model yang paling baik dari 5 (lima) model yang memenuhi syarat statistik uji Ljung-Box.

Tabel 1. Model ARIMA Tentatif $(p, d, q)(P, D, Q)^{S}$

\begin{tabular}{|c|c|c|c|c|c|c|}
\hline \multirow{2}{*}{ No } & \multirow{2}{*}{$\begin{array}{c}\text { Model ARIMA } \\
\text { Tentatif }\end{array}$} & \multicolumn{4}{|c|}{ p-value pada lag } & \multirow{2}{*}{ Kesimpulan } \\
\cline { 3 - 6 } & & 12 & 24 & 36 & 48 & Model Tidak Layak \\
\hline \hline 1 & $(1,0,1)(0,2,1)^{36}$ & 0,166 & 0,335 & 0,000 & 0,000 & Model Layak \\
\hline 2 & $(1,0,1)(1,2,1)^{36}$ & 0,965 & 0,898 & 0,692 & 0,857 & Model Tidak Layak \\
\hline 3 & $(2,0,1)(0,2,1)^{36}$ & 0,151 & 0,349 & 0,000 & 0,000 & Model Layak \\
\hline 4 & $(2,0,1)(1,2,1)^{36}$ & 0,972 & 0,899 & 0,639 & 0,824 & Model Tidak Layak \\
\hline 5 & $(3,0,1)(0,2,1)^{36}$ & 0,098 & 0,301 & 0,000 & 0,000 & Model Layak \\
\hline 6 & $(3,0,1)(1,2,1)^{36}$ & 0,947 & 0,826 & 0,545 & 0,777 & Model Tidak Layak \\
\hline 7 & $(4,0,1)(0,2,1)^{36}$ & 0,228 & 0,600 & 0,000 & 0,000 & Model Layak \\
\hline 8 & $(4,0,1)(1,2,1)^{36}$ & 0,903 & 0,821 & 0,452 & 0,712 & Model Tidak Layak \\
\hline 9 & $(5,0,1)(0,2,1)^{36}$ & 0,674 & 0,853 & 0,000 & 0,000 & Model Layak \\
\hline 10 & $(5,0,1)(1,2,1)^{36}$ & 0,811 & 0,748 & 0,416 & 0,684 & \\
\hline
\end{tabular}


Tabel 2. Rekapitulasi Pengujian Hasil Permodelan ARIMA

\begin{tabular}{|c|c|c|c|c|c|}
\hline \multirow{2}{*}{} & \multicolumn{5}{|c|}{ Model ARIMA } \\
\cline { 2 - 6 } & $(1,0,1)(1,2,1)^{36}$ & $(2,0,1)(1,2,1)^{36}$ & $(3,0,1)(1,2,1)^{36}$ & $(4,0,1)(1,2,1)^{36}$ & $(5,0,1)(1,2,1)^{36}$ \\
\hline \hline MSE & 23,05 & 22,90 & 23,12 & 24,01 & 24,22 \\
\hline KR & 6,62 & 6,00 & 5,86 & 7,27 & 7,03 \\
\hline MSD & 8,54 & 8,05 & 8,58 & 11,65 & 11,79 \\
\hline MAD & 2,11 & 2,04 & 2,08 & 2,39 & 2,39 \\
\hline MAPE & 18,89 & 18,53 & 18,86 & 21,32 & 21,38 \\
\hline MPE & $-9,31$ & $-8,98$ & $-8,99$ & $-10,38$ & $-10,19$ \\
\hline
\end{tabular}

Selanjutnya dilakukan pengujian ketepatan model dengan mencari nilai MSD (Mean Squared Deviation), MAD (Mean Absolute Deviation), MAPE (Mean Absolute Percentage Error), MPE (Mean Percentage Error) dan KR (Kesalahan Relatif). Tabel 2 menyajikan rekapitulasi hasil pengujian model ARIMA.

Dipilih model ARIMA $(2,0,1)(1,2,1)^{36}$ dengan nilai MSE, MSD, MAD, MAPE dan MPE yang paling rendah. Sedangkan nilai KR yang paling rendah adalah model ARIMA $(3,0,1)(1,2,1)^{36}$ yaitu sebesar $5,86 \%$, namun tidak berbeda jauh dengan angka KR untuk model ARIMA $(2,0,1)(1,2,1)^{36}$ yaitu sebesar $6,00 \%$. Sehingga diputuskan model yang terpilih adalah model ARIMA $(2,0,1)(1,2,1)^{36}$. Parameter model ARIMA $(2,0,1)(1,2,1)^{36}$ yang diperoleh dari output software Minitab ditunjukkan pada Gambar 9.

\begin{tabular}{|llrrrr|}
\hline \multicolumn{3}{l}{ Final Estimates of Parameters } \\
Type & & Coef & SE Coef & T & P \\
AR & 1 & 0.5136 & 0.3771 & 1.36 & 0.174 \\
AR & 2 & 0.1237 & 0.2125 & 0.58 & 0.561 \\
SAR & 36 & -0.6514 & 0.0578 & -11.26 & 0.000 \\
MA & 1 & 0.0613 & 0.3809 & 0.16 & 0.872 \\
SMA & 36 & 0.8419 & 0.0521 & 16.16 & 0.000 \\
\hline
\end{tabular}

Gambar 9. Output Parameter Model ARIMA $(2,0,1)(1,2,1)^{36}$

Sehingga diperoleh bentuk persamaan matematis untuk model ARIMA $(2,0,1)(1,2,1)^{36}$ berikut ini

$$
\begin{aligned}
\mathrm{Z}_{\mathrm{t}}= & 0,5136 \mathrm{Z}_{\mathrm{t}-1}+0,1237 \mathrm{Z}_{\mathrm{t}-2}+1,3486 \mathrm{Z}_{\mathrm{t}-36}- \\
& 0,6926 \mathrm{Z}_{\mathrm{t}-37}-0,1668 \mathrm{Z}_{\mathrm{t}-38}+0,3028 \mathrm{Z}_{\mathrm{t}-72} \\
& -0,1556 \mathrm{Z}_{\mathrm{t}-73}-0,0375 \mathrm{Z}_{\mathrm{t}-74}-0,6514 \\
& \mathrm{Z}_{\mathrm{t}-108+0,3346 \mathrm{Z}_{\mathrm{t}-109}+0,0806 \mathrm{Z}_{\mathrm{t}-110}} \\
& +0,0516 \alpha_{\mathrm{t}-37}
\end{aligned}
$$

\section{Peramalan Debit Periode 2017/2018}

Peramalan debit dilakukan dengan menggunakan model ARIMA terbaik yang telah ditetapkan. Model tersebut digunakan untuk meramalkan debit periode satu tahun ke depan, yaitu periode 2017/2018, atau sebanyak 36 data.

Peramalan debit dilakukan dengan menggunakan software Minitab 16. Input data pada software Minitab 16 adalah data debit historis sepanjang 9 tahun yaitu periode 2008/2009 s/d 2016/2017. Hasil peramalan dengan model ARIMA terbaik disajikan pada Tabel 3 dan Gambar 10.

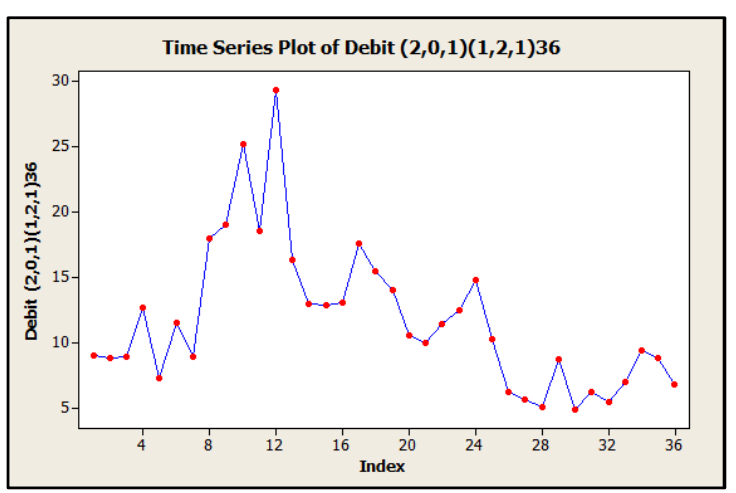

Gambar 10. Plot Debit Rata-rata 10 Harian Periode 2017/2018 Hasil Peramalan Model ARIMA $(2,0,1)(1,2,1)^{36}$ 
Tabel 3. Debit Hasil Peramalan Model ARIMA $(2,0,1)(1,2,1)^{36} \quad$ Periode Tahun 2017/2018

\begin{tabular}{|c|c|c|c|c|c|}
\hline \multicolumn{2}{|c|}{ Periode } & $\begin{array}{c}\text { Debit Model } \\
\text { ARIMA }\end{array}$ & \multicolumn{2}{|c|}{ Periode } & \multirow{2}{*}{$\begin{array}{c}\begin{array}{c}\text { Debit Model } \\
\text { ARIMA } \\
\left(\mathrm{m}^{3} / \mathrm{dt}\right)\end{array} \\
13.99\end{array}$} \\
\hline \multirow{3}{*}{$\begin{array}{l}\text { Nov } \\
2017\end{array}$} & 1 & 9.00 & \multirow{3}{*}{$\begin{array}{l}\text { Mei } \\
2018\end{array}$} & 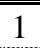 & \\
\hline & 2 & 8.80 & & 2 & 10.55 \\
\hline & 3 & 8.86 & & 3 & 9.98 \\
\hline \multirow{3}{*}{$\begin{array}{l}\text { Des } \\
2017\end{array}$} & 1 & 12.68 & \multirow{3}{*}{$\begin{array}{c}\text { Jun } \\
2018\end{array}$} & 1 & 11.37 \\
\hline & 2 & 7.23 & & 2 & 12.43 \\
\hline & 3 & 11.48 & & 3 & 14.76 \\
\hline \multirow{3}{*}{$\begin{array}{c}\text { Jan } \\
2018\end{array}$} & 1 & 8.84 & \multirow{3}{*}{$\begin{array}{c}\text { Jul } \\
2018\end{array}$} & 1 & 10.27 \\
\hline & 2 & 17.99 & & 2 & 6.20 \\
\hline & 3 & 19.02 & & 3 & 5.58 \\
\hline \multirow{3}{*}{$\begin{array}{l}\text { Feb } \\
2018\end{array}$} & 1 & 25.16 & \multirow{3}{*}{$\begin{array}{l}\text { Agt } \\
2018\end{array}$} & 1 & 5.06 \\
\hline & 2 & 18.54 & & 2 & 8.74 \\
\hline & 3 & 29.31 & & 3 & 4.85 \\
\hline \multirow{3}{*}{$\begin{array}{l}\text { Mar } \\
2018\end{array}$} & 1 & 16.36 & \multirow{3}{*}{$\begin{array}{c}\text { Sep } \\
2018\end{array}$} & 1 & 6.20 \\
\hline & 2 & 12.95 & & 2 & 5.46 \\
\hline & 3 & 12.88 & & 3 & 6.91 \\
\hline \multirow{3}{*}{$\begin{array}{l}\text { Apr } \\
2018\end{array}$} & 1 & 12.98 & \multirow{3}{*}{$\begin{array}{c}\text { Okt } \\
2018\end{array}$} & 1 & 9.35 \\
\hline & 2 & 17.53 & & 2 & 8.80 \\
\hline & 3 & 15.43 & & 3 & 6.74 \\
\hline
\end{tabular}

\section{Pola Tata Tanam Eksisting DI. Kedungkandang}

Pola tata tanam yang biasa digunakan di DI Kedungkandang adalah padi/tebu padi/tebu/palawija - padi/tebu/palawija. Untuk pola tata tanam DI Kedungkandang periode 2017/2018, pada musim tanam pertama (MT I) direncanakan penanaman padi seluas 3.304 ha dan penanaman tebu seluas 1.835 ha dengan intensitas tanaman padi sebesar $64,50 \%$. Untuk musim tanam kedua (MT II) direncanakan penanaman padi seluas 3.034 ha, tebu seluas 1.835 ha dan palawija seluas 300 ha atau intensitas tanam padi sebesar 55,79\%. Sedangkan untuk musim tanam ketiga (MT III) direncanakan penanaman padi seluas 2.124 ha, tebu seluas 1.835 ha dan palawija seluas 1.210 ha atau intensitas tanam padi sebesar $37,22 \%$.

Pola Tata Tanam Rencana DI. Kedungkandang Menggunakan Prediksi Debit Model ARIMA

Untuk musim tanam pertama (MT I) pola tata tanam mengikuti pola tata tanam eksisting, yaitu padi-tebu. Pola tata tanam ini merupakan pola tata tanam yang diinginkan karena pada masa tanam ini berada pada musim hujan sehingga ketersediaan air irigasi dari sungai bisa memenuhi kebutuhan air irigasi. Pada musim tanam kedua (MT II) tanaman palawija direncanakan akan ditingkatkan menjadi tanaman padi sehingga pola tanamnya menjadi padi-tebu. Luas tanam padi meningkat dari 2.884 ha (intensitas tanam padi 55,79\%) menjadi 3.334 ha (intensitas tanam padi $64,50 \%)$.

Sedangkan pada musim tanam ketiga (MT III) luas tanam disesuaikan dengan debit tersedia yang diperoleh dari model ARIMA, karena pada musim kemarau persediaan air irigasi dari sungai cenderung terbatas dan harus dimanfaatkan sebaik-baiknya. Optimasi dilakukan dengan menambah luas tanam padi menjadi 2.584 ha (intensitas tanam padi 49,99\%) dari nilai semula sebesar 1.924 ha (intensitas tanam padi 37,22\%), dengan mengurangi luas tanam palawija dari yang semula 1.410 ha menjadi 750 ha.

\section{Perbandingan Pola Tata Tanam Eksisting dengan Pola Tata Tanam Rencana dengan Menggunakan Prediksi Debit Model ARIMA \\ - Perbandingan luas tanam}

Pada tata tanam rencana dengan debit tersedia yang diperoleh dari model ARIMA, terjadi peningkatan luas tanam padi pada MT II dan MT III. Untuk MT II, luas tanam padi meningkat dari 2.884 ha (intensitas tanam padi 55,79\%) menjadi 3.334 ha (intensitas tanam padi $64,50 \%$ ). Sedangkan pada MT III luas tanam padi meningkat dari 1.924 ha (intensitas tanam padi $37,22 \%$ ) menjadi 2.584 ha (intensitas tanam padi $49,99 \%$ ). Untuk lebih jelasnya perbandingan luas tanam disajikan pada Tabel 4.

- Perbandingan produksi padi

Seperti sudah dijelaskan sebelumnya bahwa pada MT II dan MT III terjadi peningkatan luas tanam padi, yang berarti produksi padi meningkat pula. Rata-rata produksi padi dalam hal ini adalah gabah kering panen (GKP) adalah 7,92 ton/ha GKP. Harga jual GKP tahun 2018 adalah Rp. 4.500,00/ton Produksi gabah kering panen untuk setiap musim tanam disajikan pada Tabel 5. 
Tabel 4. Perbandingan Luas Tanam

\begin{tabular}{|c|l|r|r|r|r|}
\hline \multirow{3}{*}{ Musim Tanam } & \multirow{2}{*}{ Tanaman } & \multicolumn{2}{|c|}{ Pola Tata Tanam Eksisting } & \multicolumn{2}{c|}{ Pola Tata Tanam Rencana } \\
\cline { 3 - 6 } & & $\begin{array}{c}\text { Luas Tanam } \\
\text { (ha) }\end{array}$ & $\begin{array}{c}\text { Intensitas } \\
\text { Tanam (\%) }\end{array}$ & $\begin{array}{c}\text { Luas Tanam } \\
\text { (ha) }\end{array}$ & $\begin{array}{c}\text { Intensitas } \\
\text { Tanam (\%) }\end{array}$ \\
\hline \hline \multirow{3}{*}{ MT I } & Padi & 3334 & 64.50 & 3334 & 64.50 \\
\cline { 2 - 6 } & Palawija & 0 & 0.00 & 0 & 0.00 \\
\cline { 2 - 6 } & Tebu & 1835 & 35.50 & 1835 & 35.50 \\
\hline \multirow{3}{*}{ MT II } & Padi & 2884 & 55.79 & 3334 & 64.50 \\
\cline { 2 - 6 } & Palawija & 450 & 8.71 & 0 & 0.00 \\
\cline { 2 - 6 } & Tebu & 1835 & 35.50 & 1835 & 35.50 \\
\hline \multirow{3}{*}{ MT III } & Padi & 1924 & 37.22 & 2584 & 49.99 \\
\cline { 2 - 6 } & Palawija & 1410 & 27.28 & 750 & 14.51 \\
\cline { 2 - 6 } & Tebu & 1835 & 35.50 & 1835 & 35.50 \\
\hline
\end{tabular}

Tabel 5. Perbandingan Produksi Padi

\begin{tabular}{|c|c|c|c|c|c|c|}
\hline \multirow{3}{*}{ Musim Tanam } & \multicolumn{3}{|c|}{ Pola Tata Tanam Eksisting } & \multicolumn{3}{|c|}{ Pola Tata Tanam Rencana } \\
\hline & \multirow[b]{2}{*}{$\begin{array}{c}\text { Luas Tanam } \\
\text { Padi (ha) }\end{array}$} & \multicolumn{2}{|c|}{ Produksi } & \multirow[b]{2}{*}{$\begin{array}{l}\text { Luas Tanam } \\
\text { (ha) }\end{array}$} & \multicolumn{2}{|c|}{ Produksi } \\
\hline & & $\begin{array}{c}\text { Gabah Kering } \\
\text { Panen (ton) } \\
\end{array}$ & Penjualan (Rp) & & $\begin{array}{c}\text { Gabah Kering } \\
\text { Panen (ton) } \\
\end{array}$ & Penjualan (Rp) \\
\hline MT I & 3334 & $26,405.32$ & $118,823,938.20$ & $3,334.01$ & $26,405.32$ & $118,823,938.20$ \\
\hline MT II & 2884 & $22,841.32$ & $102,785,938.20$ & $3,334.01$ & $26,405.32$ & $118,823,938.20$ \\
\hline MT III & 1924 & $15,238.08$ & $68,571,360.00$ & $2,584.00$ & $20,465.28$ & $92,093,760.00$ \\
\hline
\end{tabular}

\section{KESIMPULAN}

Terdapat 5 model ARIMA yang layak digunakan untuk memprediksi debit rata-rata 10 harian Sungai Amprong. Dari kelima model yang layak, dipilih satu model terbaik yaitu model ARIMA $(2,0,1)(1,2,1)^{36}$ yang digunakan untuk memprediksi debit rata-rata 10 harian Sungai Amprong periode tahun 2017/2018 dengan menggunakan bantuan software Minitab 16.

Dari hasil pengujian ketepatan model dapat diketahui bahwa debit rata-rata 10 harian dengan menggunakan model ARIMA $(2,0,1)(1,2,1)^{36}$ tidak berbeda terlalu jauh dengan debit observasi periode tahun 2017/2018, sehingga model ARIMA $(2,0,1)(1,2,1)^{36}$ ini bisa diaplikasikan dalam prediksi debit rata-rata 10 harian Sungai Amprong periode tahun 2017/2018 untuk keperluan perencanaan pola tata tanam DI Kedungkandang periode tahun 2017/2018.

Berdasarkan debit tersedia dengan model ARIMA, disusun pola tata tanam rencana sebagai berikut:

- MT I : padi - tebu; dengan intensitas tanam padi sebesar $64,50 \%$.

- MT II : padi - tebu; dengan intensitas tanam padi sebesar $64,50 \%$.
- MT III : padi - palawija - tebu; dengan intensitas tanam padi sebesar 49,99\%.

Pada MT II luas tanam padi meningkat dari 2.884 ha (intensitas tanam padi 55,79\%) menjadi 3.334 ha (intensitas tanam padi 64,50\%). Sedangkan pada MT III luas tanam padi meningkat dari 1.924 ha (intensitas tanam padi $37,22 \%$ ) menjadi 2.584 ha (intensitas tanam padi $49,99 \%$ ).

Produksi GBK meningkat pada MT II sebesar $13,50 \%$ dari $22.841,32$ ton atau senilai Rp. 102.785.938,20 menjadi 26.405,32 ton atau senilai Rp. 118.823.938,20. Sedangkan pada MT III, produksi GBK meningkat sebesar 25,54\% dari $15.238,08$ ton atau senilai $\mathrm{Rp}$. 68.571.360,00 menjadi 20.465,28 ton atau senilai Rp. 92.093.760,00.

\section{DAFTAR PUSTAKA}

Arsyad, L. 1994. Peramalan Bisnis. Yogyakarta: BPFE.

Aswi \& Sukarna. 2006. Analisis Deret Waktu. Penerbit Andira, Makasar.

Chatfield. 2001. Time-Series Forecasting.

Hanggara, Ikrar dkk. 2015. Analisa Peramalan Debit Sungai Menggunakan Metode ARIMA (Auto Regressive Integrated moving Average) di Sungai Brantas Hulu. Jurnal Teknik Pengairan, 
Volume 6, Nomor 2, Desember 2015, Halaman 197-205.

Kementrian Pekerjaan Umum. (2009). Pendugaan Data Runtut Waktu Menggunakan Metode ARIMA.

Makridakis, S., S. C. Wheelwright dan V. E. McGee. 1988. Metode dan Aplikasi Peramalan. Jakarta: Erlangga.

Martani, Yustisia. 1997. Pengelolaan Irigasi. Dinas Pekerjaan Umum Daerah Tingkat I Jawa Timur. Surabaya.

Mulyana, 2004. Analist Data Deret Waktu, (Buku Ajar), Universitas Padjajaran, Jawa Barat.

Nigam, Rashmi et. al. 2009. Time Series Modeling and Forecast of River Flow. Journal of Current World Environment, Vol. 4 (1), 2009, 79-87.

Pramujo, Bambang dkk. 2015. Pemodelan Debit Menggunakan Metode Arima Guna Menentukan Pola Operasi Waduk Selorejo. Jurnal Teknik Pengairan,
Volume 5, Nomor 2, Desember 2014, Halaman 141-148.

Subagyo, Pangestu. 1986. Forecasting konsep dan Aplikasi. Yogyakarta: BPPE UGM.

Valipour, Mohammad et. al. 2012. Parameters Estimate of Autoregressive Moving Average and Autoregressive Integrated Moving Average Models and Compare Their Ability for Inflow Forecasting. Journal of Mathematics and Statistics, Vol. 8 (3), 2012, 330-338.

Valipour, Mohammad et. al. 2013. Comparison of The ARMA, ARIMA and the Autoregressive Artificial Neural Network Models in Forecasting The Monthly Inflow of Dez Dam Reservoir. Journal of Hydrology, Vol. 476, 2013, 433-441.

Zakaria, Saleh et. al. 2012. ARIMA Models for Weekly Rainfall in the Semi-arid Sinjar District at Iraq. Journal of Earth Sciences and Geotechnical Engineering, Vol. 2, No. 3, 2012, 25-55. 